\title{
DE LA MANUELA A LA MARQUESITA AVANZA EL ESCRITOR CUSTODIADO (O NO) POR LOS PERROS DEL DESEO
}

POR

LUISA VALENZUELA

Cuántas monedas, me pregunto, arroja el escritor al aire y cuántas caen y de ésas cuántas acabarán por mostrar ambas caras y entonces sabremos un poco más sobre el misterio de la creación aunque entre una y otra caída hayan pasado años.

La misteriosa desaparición de la Marquesita de Loria (1980) parecería ser la contracara de esa obra maestra titulada El lugar sin Limites (1966). Y sería su contracara radiante, intencionalmente frívola y ricamente erótica, si no fuera porque las dos novelas se tocan allí donde la máscara de la tragedia y la de la comedia se encuentran y se confunden.

Son dos miradas al infierno desde polos opuestos y complementarios, dos avatares del Cancerbero.

Como son opuestos y complementarios los respectivos personajes, la Marquesita y la Manuela: una es mujer, la otra hombre, una es joven y bella, la otra esperpéntica, una millonaria y la otra menesterosa. Pero directa o indirectamente a las dos se las llevan los perros, envueltas en harapos. Todo por haber intentado, cada una en su estilo, destrabar y vivir y sorber los secretos del sexo, beberlo hasta las heces. Sin concesiones, sin escudarse tras normas aceptadas y engañosas como las que protegen a las prostitutas y sus clientes en el lupanar de la estación El Olivo, o las que protegen a los intrascendentes aristócratas de ese Madrid de los años veinte por el que circula, un poco de contramano, la Marquesita hecha una brasa.

Así, el hilo rojo que une el vestido rojo de la Manuela al rojo camión de Pancho se torna de un gris acerado como rayo de luna para atar a la Marquesita de Loria a su némesis.

La Manuela, en la página 23, en la casilla de la Ludo:

(e)scarbó en la caja para encontrar su hilo y poder irse. La Ludo se quedó muda mientras la Manuela escarbaba. Luego comenzo a hablar.

- Le debe plata a don Alejo.

La Manuela la miró.

- ¿Quién?

-Ese que tú dices.

- ¿Pancho Vega?

-Ese.

La Manuela enrolló el hilo colorado en su dedo meñique.

- ¿Cómo sabes?

- ¿Encontraste? No te lo lleves todo. 
Pancho Vega había comprado su rojo camión con plata de don Alejo, quedando así ligado al fundo El Olivo y a su inconfesable fascinación por la Manuela. En cuanto a la Marquesita, toda pasión por ella es siempre confesada, ella no le debe nada a nadie y al contrario de la Manuela puede - y pretende - llevarse todo el hilo rojo del mundo.

Si la historia de la Manuela empieza con la intención de remendar su desgarrado vestido de española, la historia de la Marquesita empieza con sus lindos devaneos eróticos que la harán dueña de vestidos de los mejores modistas. Los harapos vendrán después: obra del perro.

Sólo que la muerte también la anda rondando, a la Marquesita, como ronda el rojo camión de Pancho por los alrededores de la estación El Olivo perdida en un Chile de miserias. Los bocinazos se oyen también en la otra cara de la moneda y ya la Marquesita es viuda de Paquito Loria en la página 55, cuando se encuentra con Tere Castillo por los muy madrileños jardines del Retiro:

-iDe un chic loco! - exclamó la de Castillo agitando las plumas un poco pasadas de moda pero "muy suyas" de su sombrero, que hacían más monumental su silueta de por sí espectacular. - ¿Por qué siempre tan sola?

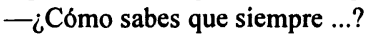

- iAh! —repuso Tere, maliciosa aunque incapaz de sutilezas-. ¡Tengo una legión de espías que me informan de todo lo tuyo!

-El luto ... la pena ...

- ¡Pamplinas, mujer! ¡Con lo soso que era el tal Paquito! ¡Tú, chiquilla, con lo bien que te ha dejado tu marido puedes imponer las reglas de tu luto a tu antojo y convertirte en la heroína de Lehar acá en Madrid! Pero ¿quién viene aquí ...? Ah, mi dilecto amigo ...

Es por el camino de la frivolidad que entra el gris a la vida de Blanca de Loria, pero será el color de su tragedia. El "dilecto amigo" llega con su gran perro gris, y por un tiempo parecería que ambos se confunden. Pero el objeto del deseo en verdad no será el hombre, sino el can. O será el can — con sus ojos gris-limón como el agua del estanque al atardecer, como la luna - la simbolización o el agente del deseo desenfrenado.

Alrededor del deseo funcionan los engaños del poder. La Marquesita cree poseerlo, como la convence Tere Castillo, la Manuela en cambio sabe que sólo puede soñar en los resquicios de la fantasía con una forma del poder —el de la seducción - cuando se pone su vestido rojo a lunares. Cada una es travesti a su manera: la Manuela es un hombre que se siente mujer, la Marquesita es una nueva rica del continente nuevo que del día a la mañana se ha vuelto aristócrata de rancia estirpe. Los perros van a desnudar a ambas, les van a robar los sueños.

Porque ambas rondan peligrosamente cerca de la magia:

En el bolsillo de su chaqueta la mano de la Manuela apretó el jirón del vestido como quien soba un talismán para urgirlo a obrar su magia.

Quizá su despiadada, apasionada muerte sea parte del milagro. Porque los caminos del deseo son inescrutables y lo que es magia para unos puede aparecer como todo lo contrario para otros (los lectores). 
La Manuela parece haber nacido sin destino, con una confusa identidad sexual que acabará con "ella". La Marquesita, en cambio, ha sido señalada desde la cuna:

... - la carne demasiado hermosa, como la suya, era cuestión de hechicería, susurraban las oscuras viejas de su infancia en la noche cuando ella era una niña que no podía dormir porque no salía la luna-.

Es por eso que la Manuela debe conformarse con perros vicarios mientras la Marquesita accede al perro propio, o casi, y el perro como corresponde se llama Luna y le abre a dentelladas la puerta de su destino.

La Manuela no tiene nada, sólo el vestido rojo de española, heredado, desgarrado, que ha de remendar para entregarse al holocausto mientras ladran los perros. Los perros, como el fundo y el camión de Pancho en un principio, son de don Alejo, el atrabiliario dios de El Olivo. Son sus perros negros, él los cría, los adiestra, los sacrifica para que siempre sean cuatro como los consabidos jinetes, "siempre perfectos los cuatro perros de don Alejandro, feroces le gusta que sean, sino, los mata". Don Alejo suelta los perros, don Alejo libera el deseo y es el dueño de todas las pasiones. Como tal, hasta logró - sin proponérselo, es cierto- que la Manuela para su propio espanto engendrara a la Japonesita. Los perros responden a don Alejo, pero por más vieja y decrépita que esté, la Manuela responde a los perros y los perros velan por ella.

Aunque en realidad ni "los cuatro perros negros de culas suntuosas, de fauces anhelantes" ni Luna "vestido de la más acariciable franela gris clara que lo enfundaba entero, incluso aquella parte que era feo ver" son de nadie. Pertenecen tan sólo a la fatalidad. ¿Por qué los soltará el autor para volver ominoso un deseo que podría desbocarse en el puro deleite? Más que soltarlos, les confiere una vida que trasciende la página. Casi como agentes moralizadores, o todo lo contrario, que viene a ser lo mismo.

Los perros victimizan a quienes subvierten las normas, a quienes saben entregarse a las pasiones. Los perros que parecen satánicos pueden ser otra cosa: el instinto no quiere que otro instinto sin freno le haga la competencia.

No cualquiera puede merecer un infierno privado. O vivir el sueño del cancerbero propio.

Perros-luna, un binomio que acompaña y llora la muerte de la Manuela:

Es que después de la lluvia el cielo se había despejado sobre la luna redonda y los perros le aullaban interminablemente, como si le hablaran o le pidieran algo o le cantaran, y como la luna no los oía porque quedaba demasiado lejos los perros de don Alejo seguían aullándole.

Perro-luna, una conjunción total en honor a la Marquesita tan bella, tan signada por los misterios de su tierra, tan rica. Tan predispuesta a la sensualidad y a todo lo que la sensualidad conlleva. “... perro terrible y maravilloso en cuyas pupilas ella podía hundirse", perro con "dos ojos como dos lunas nadando en ese infinito espacio oscuro y caliente y aromado". Conjunción que primero destrozará el entorno de Blanca de Loria para más tarde llevársela a la inexistencia en la que habita. 
Tanto para la Marquesita como para la Manuela, los mediadores entre eros y tánatos son perros que también son palabras que a su vez son pasiones. Y estos perros tienen más del autor de lo que salta (y salta es la palabra) a simple vista. Bien pueden ser tomados como metáfora de todo buen novelista: hacen y deshacen a su antojo, más que nada deshacen, desgarran, mutilan, pero nunca están en el preciso lugar donde la pasión culmina. Porque siendo ellos mismos el deseo, saben estar antes, empujándolo todo, o, como en el caso de Luna, suelen no estar en absoluto allí donde la historia los narra y desde donde mejor pueden ejercer esa fascinación del caos que revuelve las tripas, desgarra corazones y delata el otro lado del espejo. 